\title{
Comparison of functional properties of woven and knitted denim fabrics
}

\author{
DOI: 10.35530/IT.071.01.1604
}

HAFSA JAMSHAID

NORINA ASFAND

ABDUL WAQAR RAJPUT

SIKANDER ABBAS BASRA

BILAL ZAHID

AMER ALI

\section{ABSTRACT - REZUMAT}

\section{Comparison of functional properties of woven and knitted denim fabrics}

The study was aimed to develop a knitted denim fabric and investigate its properties. The said fabric has similar visual appearance to the woven denim fabric, offering additional stretch properties. The twill effect was produced on circular knitting machine using cross terry structures. Woven denim fabric was also produced to compare its properties with knitted denim. The Physical and comfort properties of these fabrics like air permeability, thermal resistance and moisture management, were investigated. Experimental investigation of serviceability i.e Pilling was also carried out. The purpose of study is to compare both woven and knitted denim fabric properties.

Keywords: woven denim, knitted denim, twill, comfort properties, physical properties, pilling

\section{Compararea proprietăților funcționale ale țesăturilor denim cu cele ale tricoturilor denim}

Studiul a avut ca scop dezvoltarea unui material textil tricotat tip denim și analiza proprietăților acestuia. Tricotul menționat are aspect vizual similar cu materialul textil țesut tip denim, oferind proprietăți suplimentare de întindere. Efectul de legătură diagonal a fost obținut pe mașina de tricotat circulară, folosind structuri cu ochiuri încrucișate. De asemenea, a fost realizată o țesătură denim pentru a compara proprietățile acesteia cu denimul tricotat. Proprietățile fizice și de confort ale acestor materiale, precum permeabilitatea la aer, rezistența termică și proprietățile de control al umidității, au fost analizate. De asemenea, a fost analizată purtabilitatea, prin efectul de piling. Scopul studiului a fost de a compara proprietățile țesăturii denim cu cele ale tricotului denim.

Cuvinte-cheie: țesătură denim, tricot denim, diagonal, proprietăți de confort, proprietăți fizice, piling

\section{INTRODUCTION}

Textiles can be considered one of the most demanding materials in the world due to their requirements in different fields of applications. They have versatile combination of properties, structures, raw materials and production techniques. With the advent of technology and research there is a desire to have substitute or modified form of each product meeting the new life styles and fashion trends. Denim fabric is one of the most popular casual wear fabrics worldwide.

It was used to produce jeans previously for workers of mining industry, but now it has become a household item, irrespective of gender, profession or age [1]. The convention with jeans is the use of woven denim fabric but knitted denim is also gaining popularity because of its better aesthetic and comfort properties. It is quickly replacing the woven denim especially in ladies and children wear [2].

Conventionally the denim is warp faced twill fabric, produced from spun cotton dyed yarn and white spun cotton used as a weft yarn. Denim is a tough warp faced woven fabric in which the warp thread passes over more than two threads. Woven denim fabrics are produced with different constructions like $3 / 1$ twill, 2/1 twill, 2/2 broken twill and 3/1 broken twill. Woven denim fabric is used for making jeans trousers, shirts jackets, skirts and bags. The woven denim structure gives better stability and durability to the fabric but lacks in proving the stretch ability as the yarn are well interlocked in the interlacement pattern. The other drawback of this fabric is the lengthy development process. The production process of denim fabric in weaving differs from the other conventional fabrics. The warp of denim is first dyed by rope dyeing and then converted to denim fabric. The production process of woven denim is therefore lengthy and also sizing and dyeing processes have raised a lot of environmental concerns [3]. The performance and comfort factors of garments during usage are very important. Generally, the comfortable stretching of fabrics according to body is good desirable properties. In recent years, due to the demand for more comfortable clothing usage of elastin, increased. Knitting is another fabric formation technique, in which elasticity is achieved even without elastin yarn. In knitting fabric is formed by Interloping of yarn. So there is need to have this structure and appearance through knitted structure that is well known to its comfort and stretch ability and better cost as there is no need of yarn preparation. Knitted fabric is generally categorized into warp and weft knitting according to the direction of loop formation. The denim effect can be achieved by three different ways. The first technique 
is float plated structure, in which the effect is produced from plating yarn. The second technique is by interlock structure, that is double knit structure and fabric is knitted on both sides to give the denim like effect. The third one is most popular and effective technique called cross terry structure. In this structure all the three basic types of stitches of weft knitting are used i.e. knit, tuck and miss. Cross terry is a type of single knit structure in which twill like pattern is achieved by joining the face yarn with ground yarn. It provides freedom to change the float length of twill faced side producing 2/1 and 3/1 terry structure [4].

This cross terry structure also provides freedom to change the float length of twill faced side to produce $2 / 1$ and $3 / 1$ terry structure pattern. In 2/1 terry structure, dyed yarn is knotted by tuck stitch followed by 2 needle float. In 3/1 terry structure, the float is extended to 3 needle followed by knotting with ground loop. The ground and face surfaces can be produced by application of different yarn tensions. Single knit weft knitting machines is generally used to produce this denim like knitted fabric. Recently different developments have also been made to produce denim structure. The different cross terry structure is developed with different float length of twill yarn.

Woven structure gives some characteristics to fabric that is superior in term of durability, strength, dimensional stability but in terms of comfort, shape retention and short production route, knitted fabrics have taken the lead. Since the denim has great demand in the market at present and knitted fabrics are popular for their shape fitting properties, softer handle, comfortable nature and high extension at low tension. Denim effect using knit structures is a new value added product in market. As far as the comparison of woven and knitted denim is concerned, there is no literature available so far particularly for thermo physiological comfort. In this study the performance property i.e. pilling and comfort properties such as air permeability, thermal properties and moisture management properties of woven and knitted denim were compared. Also the physical properties i.e. thickness was compared for both types of fabrics. All the results were evaluated with mean and standard deviation. The objective of this study is to compare both fabric techniques denim structures and generate an idea which structure has better potential in term of properties. Also the effect of yarn count within same manufacturing technique is studied.
The $100 \%$ cotton yarn with linear densities of $20 / 1$ $\mathrm{Ne}_{\mathrm{c}}$ (29.5 Tex) and 30/1 $\mathrm{Ne}_{\mathrm{c}}$ (19.6 Tex) were used for the construction of weft knitted denim to produce comparable areal density fabric as woven denim.

\section{Fabric productions}

The denim effect in weft knitted single knit fabric was produced on single cylinder machine made by Fukuhara, Japan having gauge of 20 needles per inch and machine diameter was 30 inches. The cross terry structure of $2 \times 1$ was used to produce the twill line effect in knitted fabric. Total 3 sample were produce by varying the loop length and position of yarn that is given in table 1. The knitted denim effect was obtained using cross-terry structure with 3 tracks repeat as shown in figure $1, a$.

Moreover, the woven denim was produced on Sulzer Ruti, Model P-7200 1994 (projectile weft insertion mechanism). The woven denim fabric was constructed using 3/1 Right hand twill (RHT). Total 3 samples were produce by varying the warp and weft densities. The construction of woven denim samples is given in table 1. Repeat was shown in figure $1, b$.

\section{Fabric processing}

The fabrics taken off the machines are not in relaxed state and may shrink in subsequent processing causing problem for the garment manufacturing or subsequent laundering. Therefore, it is necessary to wash the produced fabrics, allowing them to achieve normal relaxed state. Before testing, the samples were washed and tumble dried at $60^{\circ} \mathrm{C}$. This process was repeated three times. After that the sample were conditioned for 24 hour in standard atmospheric conditions, $25 \pm 2^{\circ} \mathrm{C}$ and $65 \pm 5 \%$ relative humidity.

\section{Testing}

The produced knitted denim fabric was characterized for different performance properties. The physical parameters of all the developed samples were noted in the relaxed state. Parameters like stitch length, stitch density and areal density of knitted fabric were measured. Moreover, the warp and weft densities and areal density were measured of samples.

Air permeability of both type of fabrics was measured using SDL-Atlas air permeability $021 \mathrm{~A}$ tester according to standard i.e. ASTM D737. The area of test specimen was $20 \mathrm{~cm}^{2}$ and was tested under pressure of $100 \mathrm{~Pa}$. Thermal resistance test was performed

\section{EXPERIMENTAL WORK}

Materials and method

The $100 \%$ cotton yarn with linear densities of $10 / 1 \mathrm{Ne}_{\mathrm{c}}$ (59 Tex), 11/1 $\mathrm{Ne}_{\mathrm{c}}$ (53.6 Tex), $12 / 1 \mathrm{Ne}_{\mathrm{c}}(49.2 \mathrm{Tex}), 14 / 1 \mathrm{Ne}_{\mathrm{c}}$ (42 Tex), $16 / 1 \quad \mathrm{Ne}_{\mathrm{c}}(36.9$ Tex), $18 / 1 \quad \mathrm{Ne}_{\mathrm{c}}(32.8 \mathrm{Tex})$ were selected on the basics of market well known constructions of woven denims.
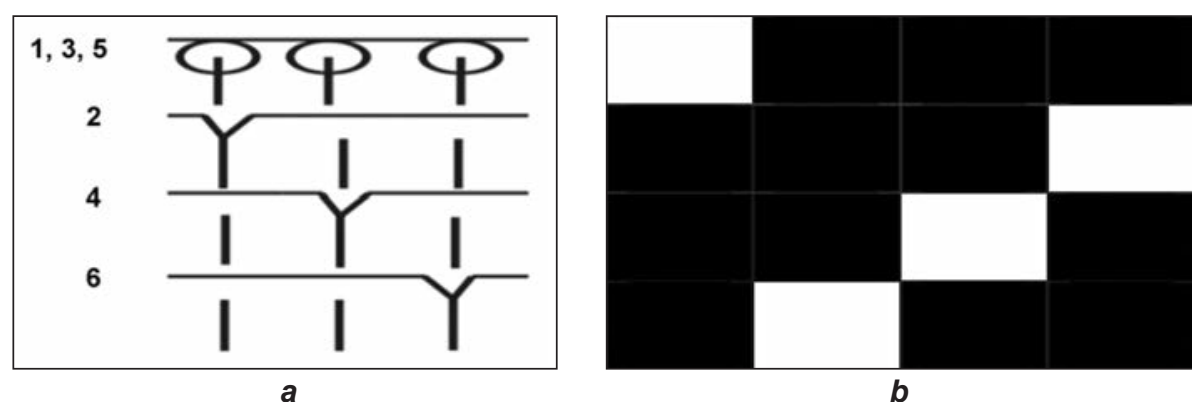

Fig. 1. Fabric structures developed: $a$ - needle repeat of $2 / 1$ terry; $b$ - weave repeat of $3 / 1$ twill 


\begin{tabular}{|c|c|c|c|c|c|c|}
\hline \multicolumn{7}{|c|}{ FABRIC CONSTRUCTION OF WOVEN AND KNITTED DENIM } \\
\hline \multirow{2}{*}{$\begin{array}{c}\text { Sample } \\
\text { ID }\end{array}$} & \multicolumn{2}{|c|}{ Woven } & \multirow{2}{*}{$\begin{array}{c}\text { Sample } \\
\text { ID }\end{array}$} & \multicolumn{3}{|c|}{ Knitted } \\
\hline & Fabric construction & $\begin{array}{c}\text { Areal density } \\
\left(\mathrm{g} / \mathrm{m}^{2}\right)\end{array}$ & & Structure & $\begin{array}{l}\text { Stitch length } \\
(\mathrm{cm})\end{array}$ & $\begin{array}{c}\text { Areal density } \\
\left(\mathrm{g} / \mathrm{m}^{2}\right)\end{array}$ \\
\hline W1 & $14 \times 18 / 92 \times 58,3 / 1 \mathrm{RHT}$ & 247 & $\mathrm{~K} 1$ & $\begin{array}{l}2 \times 1 \text { Terry } \\
\text { K-30s Ne } \\
\text { T-20s Ne }\end{array}$ & $\begin{array}{l}\mathrm{K}-0.15 \mathrm{~cm} \\
\mathrm{~T}-0.30 \mathrm{~cm}\end{array}$ & 273 \\
\hline W2 & $10 \times 16 / 76 \times 57,3 / 1 \mathrm{RHT}$ & 291 & $\mathrm{~K} 2$ & $\begin{array}{l}2 \times 1 \text { Terry } \\
\text { K-20s Ne } \\
\text { T-20s Ne }\end{array}$ & $\begin{array}{l}\mathrm{K}-0.15 \mathrm{~cm} \\
\mathrm{~T}-0.30 \mathrm{~cm}\end{array}$ & 330 \\
\hline W3 & $11 \times 12 / 73 \times 58,3 / 1 \mathrm{RHT}$ & 316 & K3 & $\begin{array}{l}2 \times 1 \text { Terry } \\
\text { K-20s Ne } \\
\text { T-20s Ne }\end{array}$ & $\begin{array}{l}\mathrm{K}-0.15 \mathrm{~cm} \\
\mathrm{~T}-0.28 \mathrm{~cm}\end{array}$ & 340 \\
\hline
\end{tabular}

Where, $\mathrm{K}=$ knit loop, $\mathrm{T}=$ tuck loop,

Where, blue/indigo dyed yarn used at tuck loop and white yarn used as knit loop

under steady state conditions using sweating Guarded Hot plate test method according to standards ISO 11092:1993. Liquid moisture management properties were measured as per standard AATCC test method 195-2012. Pilling resistance of both woven and knitted fabrics and other surface changes were investigated using Martindale tester according to standard ASTM D4970/D4970M-10e1.

The measurements of thermal properties and moisture management were repeated 5 times and for air permeability was repeated 10 times. The average and SD of data were calculated for all tests. All the measurements were made under standard atmospheric conditions.

\section{RESULTS AND DISCUSSION}

The samples of woven and knitted structures were characterized according to the standard procedure.

\section{Areal density}

The term GSM of fabric means the weight of the fabric in grams per square meter (weight per unit area). It is also known as areal density. When yarn fineness increases its areal density decreases. This phenomenon is found common to all structures. The yarn linear density (yarn count) has direct relationship with fabric areal density. The areal density of knitted fabric for same structure of fabric decreases as the yarn count become finer and increases as the yarn count become coarser. As yarn count becomes finer, no of fibers/correction decreases so weight decreases.

\section{Fabric thickness}

The denim fabric thickness was determined by thickness tester and is given in figure 2 . It shows a simple comparison of thickness of all the samples. As yarn count becomes finer, thickness decreases due to decrease of no of fibers/cross section. The knitted fabric is twice thick as compared to the woven structure. Knitted fabric is much thicker and softer than woven fabric as it has a complicated 3-dimensional structure. Knitted fabrics have loops and air space is present in the loop structure. In interloping structure, the old loop yarn has to pass over and under the new loop. By using tuck stitches in knitting, the fabric thickness increases as more yarn accumulate at the same point at clearing position. Also between sample $\mathrm{K} 2$ and $\mathrm{K} 3$, by changing stich length of tuck loop thickness increases.



Fig. 2. Fabric thickness of woven and knitted denim

\section{Air permeability}

The air permeability of woven and knitted denim sample was performed and the test results are shown in figure 3 . The air permeability of a fabric is a very sensitive indicator. Generally, the air permeability of a fabric can influence its comfort behaviours in several ways. The higher air permeability rate the quickest heat-loss obtained from a textile material. As the yarn count becomes coarser, fabric thickness increases so air permeability decreased. The results of the present study support the findings of previous studies [5-6]. The interloping structured of knitted denim allows more air to pass through the fabric. The results satisfy the facts that knitted structure have more porosity than woven structure, which cause higher air permeability value for knitted structure. Knitted fabrics have loops and air space is present in 


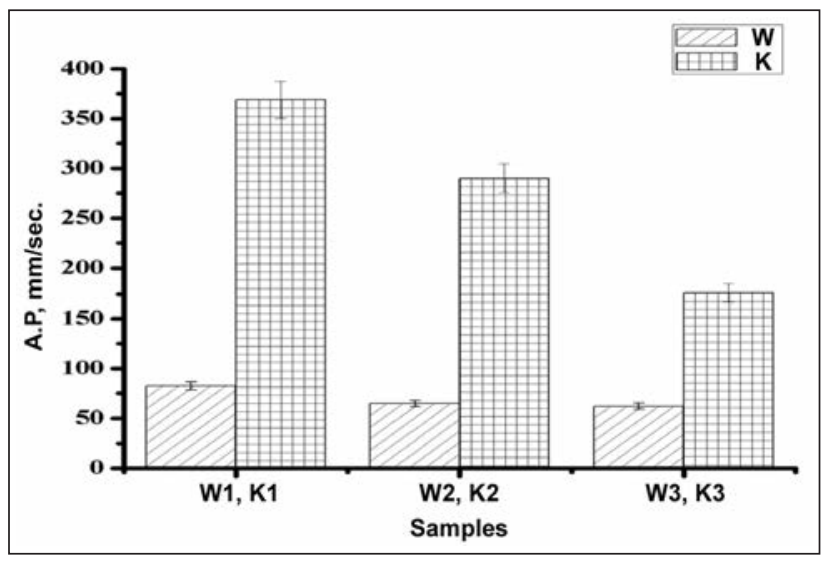

Fig. 3. Air Permeability value of knitted and woven denim

the loop structure. The permeability of fabric directly depends on the structure of the fabric (pore size and pore size distribution). The fabric having higher number of pores and pore size is more permeable [7].

\section{Thermal resistance}

The resistance results of all samples are shown in figure 4 . As count become coarser more thermal resistance value achieved. It may be due to increase of hairiness thus increasing content of air pores between loops of yarns, which leads to clogging of air. Higher level of hairiness results in more physical entrapment of air pores which leads to increased thermal insulation [8].

The thermal resistance of knitted denim is higher as compared with woven denim. This is because of interloping structure of knitted fabric which provides the gaps. The air traps in these gaps gives the results of better insulation properties. Air is known to be less heat conductive as compared to any textile fiber. Thermal Resistance of fabric mainly depends on the resistance offered by entrapped air within the fabric and inherent thermal resistance of fiber content [9] as all fiber has same content i.e. cotton, the change in the thermal resistance cannot be attributed to the material. Fabric physical properties also effect thermal properties. A higher areal density of material also contributes to the increased thermal resistance. A thicker fabric also adds to the thermal resistance of the material.

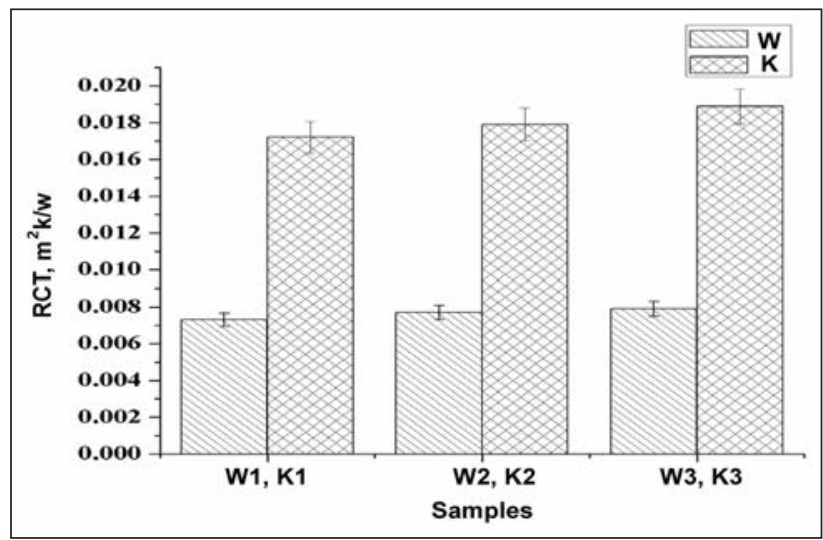

Fig. 4. Thermal resistance of woven and knitted denim

\section{Liquid moisture management test}

The Overall Moisture Management Capability (OMMC) of the knitted denim fabrics was determined using moisture management tester. A drop of test solution was dropped on the fabric surface and changes in the fabric liquid moisture content are measured in terms of electrical resistance. The moisture content changes quantify the dynamic liquid moisture transport in multiple dimensions [10]. This liquid moisture management test was performed using standard test of AATCC-195-2012. The results are shown in figure 5 . As count become coarser moisture management properties (OMMC) decreased due to indirect effect of physical properties i.e. areal density and thickness.

The moisture transport properties of knitted structure are fairly good as compared to the woven denim. These results are attributed to the cross terry structure in which more yarn surface is exposed in the fabric as compared to woven in which the yarn is interlocked in the structure. It is obvious from the results that the knitted denim has higher value of OMMC as compared to the woven, and can rapidly remove the sweat from the body by transmitting it outside of the fabric.



Fig. 5. OMMC results of woven and knitted denim

\section{Pilling test}

In pilling resistant test, the woven fabric shows better resistant to pilling as compared to knitted denim. The yarn that is used for making woven denim has higher twist (TPI) as compared to the knitted denim yarn. The results are shown in table 2 .

Table 2

PILLING COMPARISON OF WOVEN AND KNITTED DENIM

\begin{tabular}{|c|c|c|}
\hline Sr \# & Pilling for woven & Pilling for knitted \\
\hline 1 & 3 (moderate) & 2 (severe pilling) \\
\hline 2 & 2 (severe) & $2-3$ (moderate pilling) \\
\hline 3 & 3.5 (slight) & $1-2$ (v. severe pilling) \\
\hline
\end{tabular}




\section{CONCLUSION}

Knitted denim fabric and woven denim were produced to investigate the effect of certain parameters on their comfort properties (moisture management, air permeability and thermal properties. It was concluded that the knitted denim fabric exhibited better moisture management, air permeability and thermal resistance value. Although pilling resistance of woven denim is better than knitted denim. It was concluded that effect of yarn linear density also influence fabric properties. On the basic of results it can be concluded that knitted denim fabric performed better than woven structure on the basis of comfort and value. Moreover, the knitted denim provides economical products with higher potential growth for the said industry. The knitted structure can also provide variety of designs with overall better comfort values as compared with woven fabric structures.

\section{REFERENCES}

[1] Didar, S.A., Patwary, S.U., Kader, S., Akter, M.K., Ahmed, T., Development of Different Denim Effect on Knitted Fabric and Comparative Analysis with Conventional Woven Denim on the Basis of Physical and Dimensional Properties, In: Res. J. Engg. Sci., 2015, 4, 4, 9-15

[2] Dełirmenci, Z., Çelik, N., An investigation on the influence of laundering on the dimensional stability of the denim-like knitted fabrics, In: Tekst. ve Konfeksiyon, 2014, 24, 4, 363-370

[3] Walters, P., Santillo, A., Johnston, D., An overview of textiles processing and related environmental concerns, June 2005

[4] Hannan, A., Sheikh, S., Kabir, S.M.F., Hossain, A., Rouf, A., Scope of Knit Denim Products Using Reactive Dye and Convenient Washing Effects, In: International Journal of Recent Development in Engineering and Technology, 2014, 3, 5, 1-9

[5] Erdumlu, N., Ozipek, B., Investigation of regenerated bamboo fiber and yarn characteristics, In: Fibers and Textiles in Eastern Europe, 2008, 16, 43-47

[6] Herath, C.N., Investigation of air permeability of core spun cotton/spandex weft knitted structures under relaxation, In: Fiber Polym., 2013, 14, 1339

[7] Das, A., Alagirusamy, R., Sciences of clothing comfort, In: New Delhi: Woodhead Publishing, 2010

[8] Jamshaid, H., Mishra, R., Militky, J., Thermal and mechanical characterization of novel basalt woven hybrid structures, In: The Journal of the Textile Institute, 2015, 107, 4, 462-471

[9] Jamshaid, H., Mishra, R., Militky, J., Novak, J., End use performance characterization of unconventional knitted fabrics, In: Fibers and Polymers, 2015, 16, 11, 2477-2490

[10] Sampath, M.B., Senthilkumar, M., Effect of Moisture Management Finish on Comfort Characteristics of Microdenier Polyester Knitted Fabrics, In: Industria Textila, 2009, 39, 2, 163-173

Authors:

HAFSA JAMSHAID ${ }^{1}$, ABDUL WAQAR RAJPUT ${ }^{2}$, BILAL ZAHID ${ }^{3}$

NORINA ASFAND ${ }^{1}$, SIKANDER ABBAS BASRA ${ }^{1}$, AMER ALI $^{4}$

${ }^{1}$ Protective Textile Research Group, Faculty of Engineering \& Technology, National Textile University, Pakistan

${ }^{2}$ Technical Textile Research Group, BZU College of Textile Engineering, Multan, Pakistan

${ }^{3}$ Textile Engineering Department, NED University of Engineering and Technology,

Karachi -75270 , Sindh, Pakistan

${ }^{4}$ Department of Textile Science and Technology, Indus University, Karachi, Pakistan

e-mail: hafsa@ntu.edu.pk, drbilalzahid@neduet.edu.pk

Corresponding author:

ABDUL WAQAR RAJPUT

e-mail: waqar.rajput@bzu.edu.pk 